YEARBOOK

of ANTITRUST

and REGULATORY

STUDIES

www.yars.wz.uw.edu.pl
Peer-reviewed scientific periodical, focusing on legal and economic issues of antitrust and regulation. Creative Commons Attribution-No Derivative Works 3.0 Poland License.

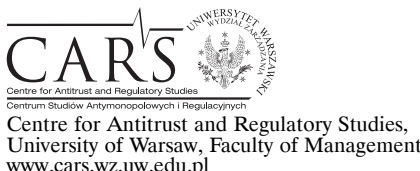

www.cars.wZ.uw.edu.pl

\title{
Disclosure of Documents in Private Antitrust Enforcement Litigation
}

\author{
by
}

Aleš Galič

\section{CONTENTS}

I. Introduction

II. Disclosure of documents pursuant to the Damages Directive

1. Introduction: from enforcement of intellectual property rights to private antitrust enforcement

2. Main features of the EU-wide litigation disclosure mechanism

3. A basic outline of special rules concerning access to the files of competition authorities

III. Limited scope of disclosure of evidence in Slovenian civil procedure

1. Documents in possession of the party adducing them

2. Documents in possession of the other party

3. Protection of business secrets?

4. Sanctions for non-compliance

5. Documents in possession of $3^{\text {rd }}$ parties and public authorities

6. Lack of specific rules for private antitrust enforcement litigation

IV. Assessment and conclusions

\section{Abstract}

Procedural tools aimed at access to information in general, and disclosure of documents in particular, are crucial for the effectiveness of private antitrust enforcement litigation and for facilitating more genuine equality of arms. Currently, profound differences exist among EU Member States' civil procedure laws concerning disclosure of evidence held by the opponent. The transposition of the litigation disclosure mechanism contained in the Damages Directive will undermine the existing principles of Slovenian

* Professor of Civil Procedure Law, University of Ljubljana, Faculty of Law, Slovenia; e-mail: ales.galic@pf.uni-lj.si. 
civil procedure. However, this is due to the fact that Slovenian law is outdated with regard to evidence disclosure. Not only that, it is also partially based on an erroneous premise, typical for the traditional civil law approach, whereby the principle against self-incrimination applies in civil cases in the same way as in criminal cases. As a result, the obligatory transposition of the Directive's requirements should be perceived as a positive step for Slovenia. Yet this step will be successful only if followed by a general reassessment of evidence disclosure rules in Slovenian civil procedure law.

\section{Résumé}

Les outils procéduraux visant à l'accès à l'information en général et à la divulgation des documents en particulier, sont nécessaires afin de garantir l'efficacité de l'application privée du droit de la concurrence et d'assurer l'égalité des armes. Actuellement, des divergences profondes concernant la divulgation de la preuve détenue par l'adversaire existent entre les procédures civiles des États membres de l'UE. La transposition du mécanisme contentieux de la divulgation de la preuve contenue dans la Directive relative aux actions en dommages va mettre en danger les principes existants de la procédure civile slovène. Cependant, cela est dû au fait que la législation slovène est obsolète à l'égard de la divulgation des preuves. De plus, cela est conséquence d'une prémisse erronée, typique à l'approche traditionnelle du droit civil, selon laquelle le principe interdisant l'auto-incrimination est appliqué dans les affaires civiles de la même manière que dans les affaires pénales. En conséquence, la transposition obligatoire des exigences posées par la Directive doit être perçue comme une étape positive pour la Slovénie. Pourtant, ce changement ne sera réussi que s'il est suivi d'une réévaluation générale des règles de divulgation de preuve incluses dans la procédure civile slovène.

Key words: disclosure of documents; privilege against self-incrimination; business secrets; principle of proportionality; civil procedure; antitrust; damages.

JEL: K23; K42.

\section{Introduction}

Antitrust damages litigation usually involves complex questions of law and facts. Such litigation cannot be effectively pursued without extensive access to information. Yet the aggrieved party rarely has sufficient knowledge of such information, or sufficient access to it. Instead, relevant information is kept secret in the hands of wrongdoers ${ }^{1}$. Antitrust damages litigation is thus

${ }^{1}$ Commission Staff Working Document Executive Summary of the Impact Assessment: Damages actions for breach of the EU antitrust rules Accompanying the proposal for a Directive 
characterized by an information asymmetry to the detriment of the claimant. It is therefore not surprising that the new Damages Directive ${ }^{2}$ puts much emphasis precisely on the rules of evidence disclosure ${ }^{3}$. Once the Directive is transposed into national laws of EU Member States - the deadline is set for 27 December 2016 - access to relevant evidence held by defendants, public authorities and $3^{\text {rd }}$ parties will be easier in antitrust damages actions brought by individuals as well as businesses.

The impact of these new instruments and their underlying policies will, however, not remain limited to the specific area of antitrust litigation. Neither will the transposition of the new rules on evidence disclosure merely require a technical adjustment of national procedural laws. On the contrary, at least some Member States will have to re-evaluate the fundamental principles governing their administration of justice in civil and commercial cases. Such developments on the EU level, although restricted to specific types of legal disputes only, might trigger a move towards a more general recognition of the duty to disclose and produce documents in national legislations ${ }^{4}$.

On the one hand, disclosure of evidence (or a further reaching US-style discovery) has long since been an integral part of civil justice in the common law procedural model. The key idea behind disclosure lies here in that the parties should, as early as possible, give advance notice of all relevant documents these include not only documents supporting their case but also those which affect their case adversely, or which support the case of their opponent ${ }^{5}$. The so-called 'cards on the table' approach strives to fulfil the overriding objective

of the European Parliament and of the Council on certain rules governing actions for damages under national law for infringements of the competition law provisions of the Member States and of the European Union, SWD/2013/0204 final.

2 Directive 2014/104/EU of the European Parliament and of the Council of 26 November 2014 on certain rules governing actions for damages under national law for infringements of the competition law provisions of the Member States and of the European Union, OJ L 349, 05.12.2014, p. 1 .

${ }^{3}$ See e.g. C. Caufmann, N.J. Philipsen, 'Who Does What in Competition Law: Harmonizing the Rules on Damages for Infringements of the EU Competition Rules?' (2014) 19 Maastricht European Private Law Institute Working Papers 5, available at: http://ssrn.com/abstract $=2520381$ or http://dx.doi.org/10.2139/ssrn.2520381 (last accessed 11 July 2015).

4 G. Wagner, 'Harmonisation of Civil Procedure: Policy Perspectives' [in:] X.E. Kramer, C.H. van Rhee (eds.), Civil Litigation in a Globalising World, Springer, Cham-HeidelbergDordrecht-New York-London 2012, p. 105.

${ }^{5}$ Cf.: 'In this country litigation [...] is conducted 'cards face up on the table'. Some people [...] regard this as incomprehensible. 'Why', they ask, 'should I be expected to provide my opponent with the means of defeating me?' The answer, of course, is that litigation is not a war or even a game. It is designed to do real justice between opposing parties and, if the court does not have all the relevant information, it cannot achieve this object'. Sir John Donaldson MR in Davies v. Eli Lilly \& Co. [1987] 1 WLR 428 (England). 
of ensuring justice, to enable better preparation and unfolding of a trial, and to prevent ambush strategies (taking the opponent by surprise) during the trial ${ }^{6}$. In addition, enabling parties to realistically assess the strength or weakness of their positions at an early stage of the case is also a powerful tool for the promotion of settlements?

On the other hand, however, the traditional approach in civil law jurisdictions is entirely different. Party access has been limited to relevant information and documents in possession of their opponent (documents which could adversely affect the opponent's civil case). Based on the German and Austrian heritage of civil procedure, the principle applied that no one was obliged to help his adversary win the case (nemo tenetur edere contra se) or 'to put weapons in the hand of its opponent' 8 . This approach perhaps derives from a serious misconception that principles of criminal procedure, notably the privilege against self-incrimination ${ }^{9}$, are easily and automatically transferable to civil cases $^{10}$. For certain additional reasons ${ }^{11}$, lack of effective access to information has been particularly characteristic for civil justice systems of post-communist countries.

Only recently has the idea been gradually gaining ground, also in civil law jurisdictions, that if effective access to justice is inherently linked to adequate results on merits, the procedural system must provide legal instruments that

${ }^{6}$ N. Andrews, English Civil Procedure, University Press, Oxford 2003, p. 597.

7 Ibidem.

8 D. Leipold [in:] Stein \& Jonas, ZPO-Kommentar, 22. Aufl., Mohr Siebeck, Tübingen 2005, para. 142 , No. 9 .

9 The principle against self-incrimination has roots in common law. In the USA, it is enshrined in the fifth Amendment which provides, inter alia, that none shall be compelled in any criminal case to be a witness against himself. The US Supreme Court defined that this privilege forbids the government from compelling any person to give testimonial evidence that would likely incriminate him/her during a subsequent criminal case (Lefkowitz v. Turley, 414 U.S. 70 (1973). It entitles a person to refuse to answer questions or provide information on the grounds that to do so might expose them to criminal prosecution (see eg Section 60 of the 2006 New Zealand Evidence Act). It should be noted that defining the extent as to which the production of documents is covered by this privilege, which originally was intended to cover merely testimonial evidence, is both very complex and difficult. For common law develompments see A. Choo, The Privilege Against Self-Incrimination and Criminal Justice, Hart Publishing, 2014, p. 2 and 56 et seq. For the case law of the ECHR see ibid, p. 25 et seq. and A. Ashworth, 'Self-Incrimination in European Human Rights Law - a Pregnant Pragmatism' (2008) 30(3) Cardozo Law Review 751-774.

10 Cf.: S. Triva, S. Belajec, M. Dika, Građansko parnično procesno pravo, Narodne Novine, Zagreb 1986, p. 425, (Yugoslavia): 'Nobody is obliged to testify against himself and to offer evidence, unfavourable to him'.

11 See infra, subsection IV. 
give parties access to items of evidence not in their possession ${ }^{12}$. Extensive rules on evidence disclosure contained in the new Damages Directive will inevitably support this trend. In this manner, at least long term, additional convergence between civil procedure laws could be achieved, and the traditional divide between civil and common law categories of civil procedures could be further diminished.

This paper aims to evaluate such possible broader impacts of the evidence disclosure rules found in the new Damages Directive for national laws of those Member States - in particular Slovenia - which traditionally have not had adequate possibilities for (prospective) claimants to obtain evidence held by others. The paper will also assess to what an extent legitimate interest (such as the protection of business secrets and the prevention of excessive burdens and costs inevitably connected with the disclosure duty) should act as a barrier for a far-reaching disclosure obligation. The key question is thus how to strike a proper balance between competing values - not only from the viewpoint of the individual interests of the given litigants. In order to enable such an assessment in the final part of the paper, a short outline of the disclosure rules found in the new Directive will be given first, followed by an assessment of the existing possibilities of access to evidence in Slovenian civil procedure law.

\section{Disclosure of documents pursuant to the Damages Directive}

\section{Introduction: from enforcement of intellectual property rights to private antitrust enforcement}

The Damages Directive is not the first EU law instrument that introduced an EU-wide litigation disclosure mechanism. Extended disclosure obligations appeared already in Directive 2004/48/EC on the enforcement of intellectual property rights ${ }^{13}$ (hereafter, Enforcement Directive). A typical feature of patent infringement litigation - like private antitrust litigation - is that claimants experience many difficulties in obtaining the evidence they need

12 N. Trocker, V. Varano, 'Concluding remarks' [in:] N. Trocker, V. Varano (eds.), The reforms of civil procedure in comparative perspective, Giappichelli Editore, Torino 2005, p. 255. Especially the English Civil Procedure Rules of 1998 (which have eliminated some extremes of US-style discovery) seem to be an important source of inspiration for legislatures in civil law jurisdictions nowadays. See e.g. C.H. van Rhee, Dutch Civil Procedural Law in an International Context [in:] M. Deguchi, M. Storme, The Reception and Transmission of Civil Procedural Law in the Global Society, Maklu, Antwerpen 2008, p. 206 et seq.

13 OJ L 157, 30.04.2004. 
to bring a successful claim. Pursuant to Article 6(1) of the Enforcement Directive, Member States must ensure that 'on application by a party which has presented reasonably available evidence sufficient to support its claims, and has, in substantiating those claims, specified evidence which lies in the control of the opposing party, the competent judicial authorities may order that such evidence be presented by the opposing party, subject to the protection of confidential information'. Furthermore, the opposing party may be ordered to produce banking, financial or commercial documents relevant to the resolution of a dispute involving the infringement of intellectual property rights on a commercial scale (Article 6(2) of the Enforcement Directive).

The Damages Directive builds on the system established by the Enforcement Directive. However, it also elaborates it further by substantially extending disclosure obligations on the one hand, and by setting out exemptions from the disclosure duty on the other. In addition, the Directive carefully addresses the complex issue of access to files held by competition authorities ${ }^{14}$. By harmonizing disclosure rules, the Directive intends, inter alia, to ensure more equality in the treatment of cartel victims across the EU, as well as to prevent excessive forum shopping. The huge divergences existing between national disclosure rules have been the very key factor in the popularity of some jurisdictions (such as the UK) with claimants seeking to bring damages actions for antitrust infringements ${ }^{15}$. On the one hand, the Directive aims to ensure that claimants are afforded the right to obtain the disclosure of evidence relevant to their claim. On the other hand, it also contains safeguards meant to ensure the protection of business secrets and legitimate privileges, as well as to prevent excessive costs and burdens. In addition, due care is given to preserving existing incentives for offending companies to voluntarily cooperate with competition authorities. Article 5 of the Damages Directive specifies the tools aimed at disclosure of evidence; Article 6 sets out further provisions relating to access to the files of competition authorities.

\section{Main features of the EU-wide litigation disclosure mechanism}

Pursuant to Article 5(1) of the Damages Directive, the court shall, upon request of a claimant, order the defendant or a $3^{\text {rd }}$ party to disclose relevant evidence which lies in their control. The same rule applies vice versa as well the defendant can also use the disclosure mechanisms against the claimant or

\footnotetext{
14 See e.g. C. Caufmann, N.J. Philipsen, supra note 3 at p. 31-32.

15 E. Burrows, R. Sander, 'Impact of the EU Directive on Antitrust Damages Actions England \& Wales - Competition Litigation 2015' [in:] Competition Litigation 2015. International Comparative Legal Guides, 7th edition, 2014.
} 
a $3^{\text {rd }}$ party (Article 5(1)). The Directive wants to prevent full scale US-style discovery and, in particular, so-called 'fishing expeditions' of non-specific searches for information which are meant to develop a case for which the party has no support yet ${ }^{16}$. However, the Directive simultaneously rejects the strict traditional civil law requirement, which states that a request for disclosure must precisely identify (specify) and describe the document sought, which is in the hands of the opponent, and that all material facts relevant to the case must be asserted already prior to the disclosure order. Recital 14 of the Directive clarifies that the effective exercise of the right to compensation can be unduly impeded by strict legal requirements for claimants to assert in detail all facts of their case at the beginning of an action, and to proffer precisely specified items of supporting evidence.

The Directive hence adopts a 'mid-way' solution. According to Article 5(2), the claimant's request can only be granted if there is a 'reasoned justification containing reasonably available facts and evidence sufficient to support the plausibility of its claim for damages' ${ }^{17}$. In this context, Recital 16 states that it follows from the requirement of proportionality that disclosure can be ordered only where a claimant has made a plausible assertion, on the basis of facts which are reasonably available to that claimant, that the claimant has suffered harm that was caused by the defendant. Article 5(2) of the Directive furthermore stipulates that the disclosure may only relate to 'specified items of evidence or relevant categories of evidence circumscribed as precisely and as narrowly as possible on the basis of reasonably available facts in the reasoned justification.' Recital 16 explains that where a disclosure request aims to obtain a certain 'category of evidence' (instead of specified items of evidence), that 'category' should be identified by reference to common features of its constitutive elements. They include: the nature, object or content of documents, the time during which they were drawn up, or other criteria, provided that the evidence falling within that 'category' is relevant for the determination of the damages claim.

When determining disclosure requests, the court is bound by the principle of proportionality. The system is based on the balancing of opposing interests in a given situation - the interests which would be favoured by the disclosure of the documents in question versus those which would be jeopardised by such disclosure. Pursuant to Article 5(3), disclosure of evidence must be limited to that 'which is proportionate, taking into account the legitimate interests of all parties and third parties concerned.' The principle nemo contra se edere tenetur

16 Cf. R. Stürner, 'Duties of Disclosure and Burden of Proof in the Private Enforcement of European Competition Law' [in:] J. Basedow (ed.), Private Enforcement of EC Competition Law, Kluwer Law International, 2007, p. 169.

17 See e.g. C. Caufmann, N.J. Philipsen, supra note 3, at p. 27. 
is explicitly rejected. Article 5(5) stipulates that 'the interest of undertakings to avoid damages actions following an infringement of the competition rules does not constitute an interest that warrants protection.' Nevertheless, legitimate interests of the party that opposes disclosure must be taken into account as well. Disclosure must be limited to what is proportionate. The Directive provides for some guidance as to the issue of proportionality. Pursuant to Article 5(3), in assessing legitimate interests of the parties and $3^{\text {rd }}$ parties concerned, the court must consider, in particular: (a) the extent to which the claim or defence is supported by available facts and evidence justifying the disclose request; (b) the scope and cost of disclosure, especially for any $3^{\text {rd }}$ parties concerned, including preventing non-specific searches for information which is unlikely to be of relevance for the parties in the procedure; and (c) whether the requested evidence contains confidential information, especially concerning $3^{\text {rd }}$ parties, and what arrangements have been put in place in order to protect such confidential information.

Hence the protection of business secrets does not, per se, constitute a ground for a disclosure refusal. On the contrary, Article 5(4) determines that the courts must have the power to order the disclosure of evidence containing confidential information where the judiciary considers it relevant to the damages action. National laws must however also ensure that, when ordering the disclosure of such information, national courts have at their disposal effective measures to protect such information. According to Recital 18 of the Directive, those measures could include redacting sensitive passages, conducting hearings in camera, limiting those allowed to view the evidence, and instructing experts to produce summaries of the information in an aggregated or otherwise nonconfidential form ${ }^{18}$. Full effect must also be given to the applicable legal professional privilege when ordering the disclosure of evidence (Article 5(6)).

National law must also equip their courts with powers to impose effective, proportionate and dissuasive sanctions for parties that refuse to comply with disclosure orders or destroy evidence. These sanctions must include the possibility to draw adverse inferences, such as presuming the relevant issue to be proven, or dismissing claims and defences in whole or in part, and the possibility to order the payment of costs (Article 8).

Another important safeguard included in the Directive relates to the right to be heard. Since the court deciding on the disclosure request must carefully weigh competing interests of both parties, and because the disclosure order can significantly affect legitimate interests of the person from whom disclosure is sought, the latter must be provided with an opportunity to be heard before a decision ordering disclosure is taken (Article 5(7)). The Directive also

18 Cf. R. Stürner, supra note 14, at p. 182. 
clarifies that (without prejudice to its provisions relating to the protection of legitimate interests of those from whom disclosure is ordered) Member States are not prevented from maintaining or introducing rules which would lead to wider disclosure of evidence (Article 5(8)). Where cross-border evidence disclosure is necessary, and a court in one Member State requests a competent court in another Member State to take evidence, or requests for evidence to be taken directly in another Member State, the provisions of Council Regulation (EC) No 1206/2001 ${ }^{19}$ apply.

\section{A basic outline of special rules concerning access to the files of competition authorities}

Documents or records held by competition authorities can be particularly valuable for victims of antitrust violations. Although it is certainly true that access to such documents is an extremely complex matter, this paper will consider it only briefly since this issue is covered specifically and in-depth by other authors in this volume ${ }^{20}$.

Already before the adoption of the Damages Directive, the Court of Justice (hereafter, CJ) has long since been confronted with questions about the relationship between effective private antitrust enforcement on the one hand, and the effectiveness of leniency proceedings on the other. In cases relating to Articles 101 and 102 TFEU, the CJ ruled that a blanket ban on access to documents held in the file of a competition authority and relating

19 Council Regulation (EC) No 1206/2001 on cooperation between the courts of the member states in the taking of evidence in civil or commercial matters. It should be noted, however, that it is practically necessary to apply the Regulation only where disclosure is requested from $3^{\text {rd }}$ parties or public authorities. On the contrary, if the disclosure is requested by the opponent and the national law provides for intra-procedural sanctions (such as drawing adverse inherences) for non-compliance, the national court does not need to use the methods of taking evidence provided by this Regulation. It is sufficient to order disclosure and, in case of non-compliance, apply procedural sanctions provided by national law. See the recent case in the UK Court of Appeal: Secretary of State for Health and others $v$ Servier Laboratories Ltd and others; National Grid Electricity Transmission plc v ABB Ltd and others [2013] EWCA Civ 1234, discussed in: J. Cary, L. Kilaniotis, A. McGregor, S. Smith, 'United Kingdom: Private Antitrust Litigation' [in:] The European Antitrust Review, 2015, Chapter 71, at footnote 35; accessible at: http:// globalcompetitionreview.com/reviews/62/sections/210/chapters/2530/united-kingdom-privateantitrust-litigation/ (last accessed 10 March 2015).

20 V. Butorac Malnar, Access to Documents in Antitrust Litigation - EU and Croatian Perspective (2015) 8(12) YARS; A. Gulińska, Collecting Evidence Through Access to Competition Authorities' Files - Interplay or Potential Conflicts Between Private and Public Enforcement Proceedings? (2015) 8(12) YARS. 
to leniency proceedings is not permitted (Pfleiderer ${ }^{21}$ and Donau Chemie ${ }^{22}$ ). The CJ rejected pleas for an almost absolute protection of voluntary, selfincriminating statements held on file by competition authorities and made by leniency applicants from disclosure to $3^{\text {rd }}$ parties which claim damages for antitrust infringements ${ }^{23}$. According to the $\mathrm{CJ}$, a balanced approach must be adopted and any request for access to the documents in question must be assessed on a case-by-case basis. This balancing of interests does not only apply to conflicting private interests of the individual parties concerned. In the course of the assessment, national courts must also consider public interests. These include, first of all, the public interest relating to the effectiveness of leniency programmes - it is essential that cartel members bona fide, and fully cooperate with competition authorities, disclose incriminating documents and voluntarily provide information concerning their knowledge of a cartel. Second, it is necessary to consider the public interest of ensuring effective private antitrust enforcement and the maintenance of effective competition through individual damages claims ${ }^{24}$. The above jurisprudence was of some, yet limited assistance to undertakings in determining the plausibility of access to leniency statements being granted by national courts ${ }^{25}$.

The Damages Directive brought much needed clarification - it aims to improve the interaction between public and private enforcement of competition rules $^{26}$. To this end, it provides that if a party or a $3^{\text {rd }}$ party is unable or cannot reasonably provide the evidence requested, national courts shall be able to request disclosure from the competition authority. EU legislation is thus well aware of the fact that information gathered by a competition authority may be very valuable for the victims of antitrust violations. At the same time, the Directive also contains safeguards meant to ensure that the effectiveness of

21 CJ judgment of 14 June 2011, C-360/09. For a critical analysis see: B. Wardhaugh, Cartel Leniency and Effective Compensation in Europe: The Aftermath of Pfleiderer, Queen's University Belfast Law Research Paper No. 23, available at SSRN:http://ssrn.com/abstract $=2330243$ or http://dx.doi.org/10.2139/ssrn.2330243 (last accessed 15 March 2015).

22 CJ judgment of 6 June 2013, C-536/11, Bundeswettbewerbsbehörde v Donau Chemie AG and Others.

${ }^{23}$ Such view was advocated also by AG Jääskinen in his opinion of 7 February 2013 in case C-536/11 Donau Chemie and Others.

${ }^{24}$ CJ judgment of 6 June 2013, C-536/11, Bundeswettbewerbsbehörde v Donau Chemie AG and Others.

25 A. Vlahek, 'Nova Direktiva 2014/104 o nekaterih pravilih glede odškodninskih zahtevkov in postopka zaradi kršitev evropskega in nacionalnega prava' [in:] P. Grilc (ed.), Liber Amicorum Bojan Zabel, Pravna fakulteta v Ljubljani, 2015, p. 181; A. Vlahek, 'Challenges of Private Enforcement of Antitrust in Slovenia' [in:] A. Gerbrandy, M. Kovač (eds.), Economic Evidences in EU Competition Law. European Studies in Law and Economics, Intersentia, MortselCambridge 2015, forthcoming (Chapter: Disclosure of documents).

26 See e.g. C. Caufmann, N.J. Philipsen, supra note 3. 
public antitrust enforcement is protected and in particular, that the incentives for offending companies to voluntarily cooperate with the authorities are not diminished ${ }^{27}$. Article 6(6) of the Directive clearly states that leniency statements and settlement submissions are immune from disclosure - a rule considered to be a welcome step forward from the somehow reserved positions of the $\mathrm{CJ}^{28}$. The EU legislature duly recognized that allowing such disclosure would be act as a disincentive for potential leniency participants, and without effective leniency programmes, many cartels would not be discovered at all (Recital 26). In order to safeguard the public interest, which might be jeopardized by ordering disclosure, a competition authority may submit observations on the proportionality of a disclosure request to the national court before which a disclosure order is sought (Article 6(11)).

The disclosure of certain other categories of evidence (such as responses to requests for information, information prepared specifically for the proceedings, information drawn up by the authority and sent to the parties) may only be ordered after the competition authority has closed its proceedings. Strict limits on use apply to evidence that has been obtained solely through access to the file of a competition authority. In general, however, all other evidence in the file of a competition authority is disclosable, provided that the principle of proportionality is complied with. This should, as explained in Recital 27, ensure that injured parties retain sufficient alternative means by which to obtain access to relevant evidence, which they need in order to prepare their actions for damages. Recital 22 states in addition that in order to ensure the effective protection of the right to compensation, it is not necessary for every document relating to Article 101 or 102 TFEU proceedings to be disclosed. According to the Directive, it is highly unlikely that the damages action will need to be based on all evidence accumulated in the public enforcement file. In this regard, Recital 23 further explains that particular attention should be paid to preventing 'fishing expeditions'. Disclosure requests should thus not be deemed to be proportionate where they refer to the generic disclosure of documents in a given case file of a competition authority, or the generic disclosure of documents submitted by a party in the context of a particular case. In any event, it is necessary to distinguish between documents prepared 'for' or 'in the course of' public enforcement proceedings versus those documents that exist independently of the proceedings of a competition authority ('preexisting information'). The latter category of documents is fully disclosable (Recital 28).

Another important instrument aimed at greater effectiveness of private antitrust enforcement is set out in Article 9 of the Directive. Claimants in

27 Ibidem, p. 31-32.

28 B. Wardhaugh, supra note 18. 
antitrust damages actions will further be able to rely on a final decision of a National Competition Authority (hereafter, NCA) that establishes an infringement. Such decisions will automatically constitute proof of the violation before courts of the Member State where that infringement occurred ${ }^{29}$. This rule is of great practical importance, given the fact that almost all individual antitrust damage actions take the form of 'follow-on actions', that is, they are brought forward only after the decision of a competition authority regarding an antitrust infringement was adopted. Such rule existed, so far, only in some EU Member States (Slovenia including; see infra Section 3.6).

\section{Limited scope of disclosure of evidence in Slovenian civil procedure}

\section{Documents in possession of the party adducing them}

It is understandable that parties are required to produce documents in their possession, to which they themselves have made reference. As this will normally concern documents that support the party's case, it is in principle in the party's own interest to produce them ${ }^{30}$. Still, a major practical dilemma surrounds the question when exactly such documents should be produced. It should be noted that Slovenian civil procedure does not have a general pre-trial disclosure rule. Pursuant to the Yugoslav Civil Procedure Act of 1976, parties were free to submit new facts and evidence until the end of the last session of the main hearing. Such system did not allow for a proper organization of the preparatory stage of the litigation, the structuring of the proceedings, the early identifying of disputed, or the relevant issues of the case. It was also not able to prevent the common - and yet outright fatal from the efficiency point of view - practice whereby attorneys filed further preparatory briefs, adducing new facts and evidence, as late as during the main hearing. The lack of effective tools ensuring the timely gathering of procedural materials used to result in frequent

29 A decision of a foreign NCA does not have such conclusive effects but claimants can rely on them as if they amount to at least prima facie evidence of the infringement.

30 The party's consideration might be different if such document contains business or trade secrets. However, the party must take into account that if it submits the document to the court, the opponent will inevitably get full access to it. The option that business and trade secrets could be protected in civil litigation by way of some sort of a 'secret trial' so as to keep them secret from the opponent (and disclosed solely to the court or a court-appointed expert entrusted with the task to inspect the document and provide its non-confidential, edited summary) was rejected by Slovenian courts (Ljubljana Court of Appeals No. I Cpg 708/2013 dated 21 November 2013). The party who chooses to submit documents to the court must take into account that these documents will inevitably be accessible to its opponent ('lose the case or lose the secret'). 
adjournments of hearings. It also resulted in a 'piecemeal' manner in which the facts and evidence of the case were being presented, and in culpably delaying a case's progress. Another feature of the former system's litigation style was the frequent use of 'ambush tactics' by attorneys. Since there were no time limits for the adduction of fresh evidence, and no obligation regarding advance disclosure, parties often filed documentary evidence only at the oral hearing. As such, they counted on the other party being taken by surprise. Admittedly though, such late disclosure of relevant evidence was often not the result of a deliberate tactic, but a mere consequence of negligent case preparation, or, more often, a tool that enabled the achievement of a desired adjournment ${ }^{31}$.

Already the first Slovenian Civil Procedure Act of 1999 (hereafter, CPA ${ }^{32}$ ) introduced the rule that parties may assert new facts and evidence no later than at the first main hearing. At a latest stage, parties are allowed to present new facts and new evidence only with a proper justification for the belated submission (Article $286 \mathrm{CPA}$ ). Further steps were taken through an amendment in $2008^{33}$. In order to enable the opposing party's right to be heard and organize its case, the other party is now obliged, whenever possible, to file new preparatory briefs in sufficient time for them to be served on its opponent, with adequate time before the main hearing. Furthermore, judges now have the discretionary power to require (and to impose binding time limits) that parties make further submissions and clarifications concerning facts, evidence and legal positions in a set time limit (Article 286a(1) CPA). The judge may exercise this discretion already in a written form before the main hearing. The system of procedural sanctions is flexible. The judge is empowered, but not obliged, to use the above tools - he has the discretion to relieve the parties of the sanctions. It is moreover acknowledged that preclusions restrict the parties' right to be heard and thus they should be applied carefully and so as to ensure a proper balance between competing policies ${ }^{34}$.

\section{Documents in possession of the other party}

In Slovenian (and former Yugoslav) civil procedure, a party has limited access to relevant information and documents held by its opponent and which could adversely affect the opponent's case. Traditionally, based on the

31 See also A. Uzelac, 'Survival of the third legal tradition?' 2010 Supreme Court Law Review 384.

32 Zakon o pravdnem postopku, Official Gazette, No. 26/99.

33 Zakon o spremembah in dopolnitvah Zakona o pravdnem postopku (ZPP-D), Official Gazette, No. 45/2008.

34 Judgment of the Supreme Court of Slovenia No. II Ips 197/2009 of 7 April 2011. 
German and Austrian heritage of civil procedure, the principle applied that no one was obliged to help his adversary win the case (nemo tenetur edere contra se $)^{35}$. Hence, the Slovenian CPA only provides for a rather narrow scope of the duty to produce documents upon request of the opposing party (Article $227 \mathrm{CPA})^{36}$. First of all, a party can request that the opponent produces documents, which the latter itself has referred to in its pleadings, without any restrictions. Second, a party can request disclosure when the opposing party, under substantive laws ${ }^{37}$, has a legal duty to produce certain documents (for instance: share-holders vis-à-vis a corporation ${ }^{38}$, agents vis-àvis their principals, keepers of accounting books). Finally, a party can request the disclosure of documents which are, due to their contents, regarded as mutual for both parties (for example, a contract between these parties). In the abovementioned circumstances, the obligation to produce the requested documents is absolute ${ }^{39}$.

Different rules apply for all other documents material for a given case. If the requesting party is aware of the existence of such documents, and can identify them to a sufficient degree (and can also explain how the documents requested are relevant to the case and material to its outcome), the other party that holds them may be required to produce them. However, the duty to disclose is not absolute here as the rules determining witnesses' privileges (cases where witnesses are excused from the obligation to testify) apply mutatis mutandis (Article 227 CPA and Articles 231-234 CPA). Hence, disclosure of a document may be denied if the document relates to what the party has confessed to the possessor of the document as their legal counsel (or their religious confessor), or facts discovered while acting as a lawyer, a doctor or in pursuit of another profession, if bound by the duty to protect the confidentiality of communications made during the pursuit of such professions

35 S. Triva, V. Belajec, M. Dika, supra note 10, at p. 425.

${ }^{36}$ It is unclear whether data stored in an electronic form (eg documents that are stored on servers or back-up systems, email and other electronic communications, word-processed documents, documents stored on memory sticks and mobile phones) are considered documents or tangible things subject to proof by observation (see e.g. J. Zobec [in:] L. Ude, Pravdni postopek - zakon s komentarjem [Civil Procedure: Act with the Commentary], vol. 2, GV Založba in ČZ UL, Ljubljana 2006, p. 419; compare also R. Stürner, supra note 14, at p. 174). However, the dilemma is not really practically important since the rules concerning the duty to disclose and the right to deny disclosure, applicable to documents, apply mutatis mutandis also to the inspection of tangible things in the possession of the opponent or $3^{\text {rd }}$ persons (Art. $222 \mathrm{CPA}$ ).

${ }^{37}$ It has not be settled yet either in case-law or legal writing whether the reference to the statutory duty to submit a document should be construed broadly and hence include also cases where such duty is established on a contractual basis.

38 See e.g. judgment of the Ljubljana Court of Appeals No. I Cpg 590/2006.

39 C.f. M. Brkan, T. Bratina, 'Private Enforcement of Competition Law in Slovenia: A New Field to Be Developed by Slovenian Courts' (2013) 6(8) YARS 86. 
(Article 231 CPA). Nevertheless, the document may not be withheld on the grounds of the protection of a professional secret (applicable, for example, to attorneys at law, medical doctors, mediators, bankers, journalists etc) if the disclosure of certain facts is to the benefit of the public or some other person, provided that such benefit outweighs the damage caused by the disclosure of the secret (Article $232 \mathrm{CPA}$ ). A proportionality test must be applied here.

Moreover, a document may also be withheld if by producing it the party might expose herself, her spouse or her close relatives to a serious disgrace, considerable financial loss or criminal proceedings (Article $233 \mathrm{CPA}$ ). In such an event, the right to withhold the document is absolute, thus, irrespective of whether the benefit of disclosure for the requesting party would outweigh the damage caused by it to the possessor of the document.

The above system enables therefore only a limited scope of documents disclosure. The first key difference between this system and the common law approach is that in Slovenia a party has no duty to disclose unfavourable documents in its possession on its own motion. Although the law establishes the obligation of truth for the parties (Article 9 CPA), this is merely a proclamation without any sanctions and adverse consequences for non-compliance attached to it. The second major difference is that a party seeking disclosure in Slovenia must sufficiently identify the document it is requesting ${ }^{40}$. A request for the presentation of a document can only be successful if the party is able to describe its content in sufficient detail so as to clearly identify it. This rule is hence only useful for preventing the concealment of documents, the existence of which is already known. It is not useful for documents the content or existence of which is not sufficiently known to the requesting party. This system fails to facilitate any kind of discovery of new information ${ }^{41}$ and purely exploratory evidence is not admissible ${ }^{42}$. The duty of the opponent to produce documents only applies if the requesting party has submitted its substantiated pleadings and explained its cases in detail beforehand. It should also be noted that in line with the continental tradition (and in contrast to the US-style of 'notice pleading'), the principle of fact pleading applies in Slovenian civil procedure. This means that a party must plead detailed facts and offer specified means of evidence already in the statement of its claim. According to the continental procedural tradition of fact pleading, the judge will only order the taking of evidence on individual facts that have been asserted by the party.

Parties often try to avoid this limitation by requesting 'the entire correspondence' or 'all documents relating to a certain transaction' to be

${ }^{40}$ Cf. N. Bucan Gutta, The Enforcement of EU Competition Rules by Civil Law, Maklu Uitgevers, 2014, p. 224.

41 Judgment of the Supreme Court No. II Ips 544/2002, dated 11 September 2003.

${ }^{42}$ See e.g. judgment of the Supreme Court No. II Ips 560/2006. 
disclosed, but courts are usually quite restrictive in this regard ${ }^{43}$. Disclosure orders involving generic categories of documents are not allowed ${ }^{44}$. It should be noted in addition that a party cannot demand the opponent to disclose evidence - only the court is authorized to do so upon a party's motion. More importantly, a court order for document disclosure cannot be rendered at the preparatory stage of civil litigation - it can only be issued after the commencement of the main hearing - disclosure mechanisms are thus designed to be used after the commencement of the main hearing. Consequently, they can hardly contribute to a better preparation of the trial, and even less so to stimulate settlements at an early stage of the proceedings. It has been already mentioned that since the amendment of the CPA that took place in 2008, judges have the powers to order documents to be produced already before the main hearing. But this - at least according to the wording of the law - merely relates to documents in possession of that procedural party which has, in its pleadings (the claim, the defence plea), adduced (but still not produced) them. Unfortunately, there is no explicit provision authorizing the court to order, in the preliminary stage of the proceedings, a party to produce documents in its possession which the other party has adduced as evidence.

\section{Protection of business secrets?}

The material scope of disclosure in the Slovenian CPA is relatively broad. It is important to note that the right to seek documents is not (as has traditionally been the case in civil law jurisdictions ${ }^{45}$ ) restricted to cases where an independent substantive right to possession exists. The disclosure duty extends to documents, the production of which is sought solely on the basis of their relevance to the pending case. It seems, however, that the legitimate interests of the possessor of the requested documents have not been adequately protected. It is especially noteworthy that the protection of trade and business secrets is not explicitly mentioned as a legitimate ground for a disclosure refusal (as it is not a reason for excusing a witness from the duty to testify $)^{46}$. The protection of trade and business secrets is merely a ground

43 See e.g. judgment of the Ljubljana Court of Appeals No. I Cpg 1205/2001: '(...) the law refers to specificic, individualized documents, invoked by the party, and not to any documents relating to the case or even some undefined and undefinable documentation'.

44 N. Bucan Gutta, supra note 37, at p. 224.

45 Compare N. Trocker, V. Varano, supra note 11, at p. 255.

46 Compare M. Testen, 'Vloga odvetnika pri pridobivanju in (ne)razkritju dokazov za namen pravdnega postopka' ['The Role of the Attorney in Obtaining and (Non)disclosure of Evidence for the Purpose of Civil Proceedings'] (2011) 6-7 Podjetje in delo 1506. 
for exclusion of the public from all or part of the main hearing, as well as excluding the general public from access to the court file (Article $230 \mathrm{CPA}$ ). This however does not solve the problem where a party wishes to safeguard its business secrets vis-à-vis its opponent, which might in the same time be its competitor, and to prevent serious damage that could result from improper communication of business secrets to such a party ${ }^{47}$. Protection of professional secrets (relating to jobs where the confidentiality of the professional-client relationship is essential; such as the explicit examples given in the CPA: a lawyer, a doctor or a priest) makes it possible to withhold documents. However, professional secrets are only rarely identical to trade and business secrets ${ }^{48}$. Only if a very broad understanding of the term 'professional secrets' is adopted, it could also include business secrets ${ }^{49}$.

Certain authors have suggested therefore that protection of business secrets could be covered by the provision that documents can be withheld if by producing them the party would expose himself (inter alia) to a 'considerable financial loss' or for 'other compelling reasons' (Article $233 \mathrm{CPA})^{50}$. This seems like a plausible definition. A problem remains however in that - unlike with professional secrets and attorney-client privilege - the right to withhold documents due to a threat of considerable financial loss is unrestricted. No test of proportionality applies here and the court cannot rule that the benefit of producing the document outweighs the damage caused by disclosure of certain business secret. This is, again, not a proper solution. The protection of trade and business secrets should be a legitimate ground for a denial to disclose documents, but not on absolute terms. It is necessary to strike a proper balance between competing values - the right of effective access to the court and the right to be heard versus the protection of confidentiality and business secrets.

47 Cf. N. Bucan Gutta N., supra note 37, at p. 221.

48 V. Bergant Rakočević, 'Varstvo uradne, vojaške in poslovne tajnosti v civilnem sodnem postopku' ['Protection of official, military and commercial confidentiality in civil proceedings'] (2011) 6-7 Podjetje in delo 1483; J. Zobec, supra note 33, at p. 445.

49 One author suggests that 'professional secrets' referred to in Art. 232 CPA are something different from 'professional privileges' in Art. 232, and could thus cover also the notion of 'business secrets' (N. Bucan Gutta, supra note 37, at p. 221). But this author fails to see that Art. 232 CPA does not establish a new category of non-disclosable information, but merely adds additional requirements concerning one category of non-disclosable information as determined in Art. 231 CPA. In other words, Art. 231 CPA postulates that members of certain professional groups are entitled to refuse testimony, while Art. $232 \mathrm{CPA}$ in relation to this rule adds that when the protection of professional secrets is invoked, the court must apply the proportionality test. It is thus beyond doubt that in the CPA the notion of a 'professional secret' is used as a synonym for a 'professional privilege'.

50 Cf. ibidem. 
The protection of trade and business secrets should thus not form an unconditional and absolute ground for withholding documents. The court should be authorized to weigh up the respective interests in order to establish a proper balance between the adversarial principle and the right to protect business secrets ${ }^{51}$. A solution that offers a compromise should be possible such as: restricted access to the documents or; the redaction of its sensitive parts provided it still provides the requesting party with sufficient information and; if there is a legitimate interest on the part of a party or $3^{\text {rd }}$ party to do so. However, no such instruments exist in current Slovenian legislation and neither have they been developed by the courts.

\section{Sanctions for non-compliance}

The question has to be considered also of the consequences of an opponent failing to produce the required document ${ }^{52}$. Before the 2008 CPA reform, the law provided that the court would assess, within its discretion and taking into account all circumstances of the case, the significance of the fact that the party possessing a document failed to comply with a court order to produce it, or if the company asserted, contrary to the court's belief, that it was not in possession of such document. When it came to the determination of the claim, this usually meant in practice that the court drew adverse conclusions from any refusal to produce readily available documents ${ }^{53}$. This solution was reasonable, adequate and at the same time flexible.

Nevertheless, the Slovenian legislature chose to change the old system in 2008 and introduced a sanctions model for non-compliance which is both harsher, as well as more rigid than its predecessor. Now, if a party does not

51 For the specific area of antitrust litigation (claims for damages for infringement of competition law) compare the proposal for the Directive on certain rules governing actions for damages under national law for infringements of the competition law provisions of the Member States and of the European Union (http://www.europarl.europa.eu/sides/getDoc. do? pubRef $=-/ / \mathrm{EP} / / \mathrm{NONSGML}+\mathrm{AMD}+\mathrm{A} 7-2014-0089+002-002+\mathrm{DOC}+\mathrm{PDF}+\mathrm{V0} / / \mathrm{EN})$. Recital 17 of the proposal states that 'while relevant evidence containing business secrets or otherwise confidential information should in principle be available in actions for damages, such confidential information needs to be appropriately protected. National courts should therefore have at their disposal a range of measures to protect such confidential information from being disclosed during the proceedings'.

52 First it should be noted that the order that the opposing party must produce the documents is not enforceable. The court has no power to force the opponent to produce such documents even if the requesting party has a legal right to obtain it. The only remaining possibility is to bring a separate claim for handing over of the document in question (actio ad exhibendum);

L. Ude, Civilno procesno pravo [Civil Procedure], ČZ UL, Ljubljana 2002, p. 267.

53 M. Brkan, T. Bratina, supra note 36 , at p. 87. 
comply with an order to produce a document (which the court believes is in its possession), the court must regard the facts alleged by the requesting party, and supposedly supported by the document in question, as true. Presumably, the novelty was supposed to be in line with Paragraph 427 of the German Zivilprozessordnung (hereafter, ZPO) ${ }^{54}$. This, however, is not the case. In Germany, allegations made by the party tendering evidence regarding the nature and content of a document may be assumed to be proven in the case of a failure to comply with the order to produce that document. The differences between the German and the Slovenian rules are significant.

First of all, German judges retain their discretion not to draw adverse inherences from the failure to comply with a disclosure order ('may'), unlike the Slovenian solution which obliges them to do so ('shall'). Much more importantly, however, the German rule that the asserted content of a given document is considered proven (Paragraph 427 of the German ZPO) is much less far reaching than the Slovenian rule, whereby material facts, intended to be proven by the document in question, shall be considered proven (Article 227(5) of the Slovenian CPA). The German rule is much more appropriate. After all, in a system where evidence is freely evaluated (where judges must weigh all evidence), even if the document was submitted and its contents were indeed such as the requesting party had contended, this would not automatically mean that the party would inevitably succeed in proving the facts, which it intended to prove relying on this document.It is not clear why the Slovenian legislature opted to change the previous flexible sanction system for the party's non-compliance with the court's disclosure order. It might be just one further expression of the general animosity towards judicial discretion in Slovenia, and a persistent preference of the national legal community for a rigid procedural regime.

\section{Documents in possession of $3^{\text {rd }}$ parties and public authorities}

Persons other than procedural parties may be ordered to submit documents only if such a duty is imposed upon them by substantive law or if, concerning the contents of a document to be submitted, it was created both for this $3^{\text {rd }}$ person and the party adducing it as evidence. Unlike the order directed to the other procedural party, the order for the production of documents directed to a $3^{\text {rd }}$ person is directly enforceable (Article $228 \mathrm{CPA}$ ). Nevertheless, the law is extremely unfavourable for the party relying on a document in the possession of a $3^{\text {rd }}$ person. There is no right to produce the document if the

54 J. Zobec, supra note 33, at p. 177. 
request is based solely on the document's relevance to the pending case, no matter whether the possessor has any legitimate interests to withhold it or not. The legislature entirely failed to strike a balance here between the legitimate interests of litigants (and their constitutional right of effective access to the courts) and the legitimate interests of $3^{\text {rd }}$ parties which possess relevant documents.

The present Slovenian system has been criticized for being too restrictive and for its logical inconsistencies. It is unreasonable that a $3^{\text {rd }}$ party may be obliged to testify about the content of a certain document in its possession, but is nevertheless not obliged to produce this document in a court ${ }^{55}$.

If a document (relied upon by a party) is held by a public body, and if the latter refuses to produce it, the court may demand its production $e x$ officio (Article 226(3) CPA). In addition, the court also has a general power to request that public authorities or public officials communicate records or provide official information (Article $10 \mathrm{CPA}$ ).

\section{Lack of specific rules for private antitrust enforcement litigation}

There are no specific rules relating to evidence for antitrust damages actions in the CPA. Neither are such rules included in the Prevention of Restriction of Competition Act of 2008 (hereafter, PRCA- ${ }^{56}$ ), which is, in general considered to be a modern piece of competition legislation ${ }^{57}$. Hence, the above presented general regime of the CPA is also fully applicable to private antitrust enforcement. The Public Information Access Act ${ }^{58}$, and its provisions on exceptions to grant access, are also applicable but they do not ensure the desired degree of predictability and legal certainty either; neither do they properly balance competing interests specific for private antitrust enforcement. This is a highly unsatisfactory situation as it jeopardizes the effectiveness of both private enforcement (Article 62 PRCA-1) as well as public enforcement of Slovenian competition law.

A particularly high degree of uncertainty concerns the issue of access to documents held in the file of the Slovenian NCA - the Javna agencija Republike

55 M. Testen, supra note 43, at p. 1507; J. Zobec, supra note 33, at p. 433.

56 In Slovenian Zakon o preprečevanju omejevanja konkurence (ZPOmK-1), Official Gazette RS, No. 36/2008, as amended; entered into force on 26 April 2008; English version of the Act (without its latest amendements of 2014) is available at: http://www.varstvo-konkurence.si/ fileadmin/varstvo-konkurence.si/pageuploads/ZPOMK-1-EN_consolidated_2013.pdf

57 See: A. Fatur, K. Podobnik, 'SI/C Slovenia/Commentary' [in:] Competition Law in Western Europe and the USA, Wolters Kluwer, 2014, Chapter SI.C-1.

58 Zakon o dostopu do informacij javnega značaja - ZDIJZ (Official Gazette No. 24/03). 
Slovenije za varstvo konkurence - with respect to its leniency programme ${ }^{59}$. The Decree on the procedure for granting immunity from fines and reduction of fines in cartel cases (hereafter, the Decree ${ }^{60}$ ) merely states that leniency applications are deemed to be business secrets ${ }^{61}$. However, the very question to what an extent do business secrets constitute a legitimate ground for a disclosure refusal, has not been adequately solved in Slovenian law. There are also no procedural tools which would enable disclosure of documents in such a way that would guarantee that business secrets are protected to the greatest possible extent ${ }^{62}$. The question whether such disclosure must also take place following a court request in an individual damages action is not answered by Article 6 of the Decree either. The latter states only that the NCA 'may only disclose information and evidence from an application to a company under an infringement procedure after a statement of the objections has been issued in an administrative procedure and in accordance with paragraph 7 of Article 18 of the Act'. The PRCA- 1 does include rules on access to the files of the $\mathrm{NCA}^{63}$. However, these provisions apply only to the NCA's administrative proceedings (and are addressed to the parties of those proceedings). They do, not apply to private enforcement proceedings or to requests for disclosure which are made by courts ${ }^{64}$. Fatur, Vlahek and Podobnik therefore observe that 'it is yet to be seen how this issue is tackled by Slovenian undertakings and authorities' and that 'it will also be particularly interesting to see how the new directive is implemented in Slovenia' ${ }^{65}$. For the time being though, leniency participants cannot be sure that their leniency statements will not be disclosed in follow-on actions if so requested by the claimants in these proceedings ${ }^{66}$.

59 The Slovenian leniency programme has been implemented by the PRCA- 1 of 2008 in order to align the competition regime regarding fines with that of the EU. It was, however, not actually launched until January 2010. See A. Fatur, K. Podobnik, A. Vlahek, 'Competition Law - Slovenia' [in:] F. Denozza, A. Toffoletto (eds.), International Encyclopaedia for Competition Law, Kluwer Law International/Wolters Kluwer, forthcoming (expected date of publication 2015), Chapter 5, § 1, IV B.

60 Official Gazette RS, No. 112/09.

61 Article 6 of the Decree.

62 For a partially different view see: N. Bucan Gutta, supra note 37, at p. 222-223.

63 Art. 12b(4) of the PRCA: 'Notwithstanding the provisions of the act regulating access to public information, the Office shall refuse a person requesting access to public information access to information relating to the secrecy of the source and to information constituting a business secrets of undertakings'.

64 Judgment of the Ljubljana Court of Appeals No. I Cpg 708/2013 of 21 November 2013.

65 See A. Fatur, K. Podobnik, A. Vlahek, supra note 56.

66 A. Fatur, K. Podobnik, supra note 54, Chapter SI.C-35: 'The leniency programme as regulated by Article 76 of the Competition Act provides for immunity from fines as well as for reduction of fines to potential whistle-blowers. Its characteristics are mainly aligned to the 2006 Commission notice on immunity from fines and reduction of fines in cartel cases, whereby the 
Yet since the offender's voluntary submission of incriminating documents to the NCA is a key requirement of the Slovenian leniency programme ${ }^{67}$, it is not surprising that it has thus far been only very rarely applied in practice ${ }^{68}$.

On a more positive note, Slovenia is one of the few Member States that have already, prior to the transposition of the Damages Directive, ensured that claimants in antitrust damages actions are able to rely on a final decision of their NCA (as well as the European Commission) finding an antitrust infringement. In follow-on actions, such decisions automatically constitute proof before the court that the infringement occurred (Article 62(2) of the PRCA-1).

\section{Assessment and conclusions}

The privilege against self-incrimination is a principle of criminal procedure and like with many other properties of the law of evidence, one should be cautious when applying such doctrines to civil cases. Undoubtedly, in the context of documents disclosure in civil procedures, the privilege against selfincrimination is legitimately applicable insofar as it relates to a party exposing itself to the risk of being prosecuted for a criminal offence ${ }^{69}$. It is, however, an entirely different question whether this privilege should also apply if a party would, by disclosing evidence unfavourable to itself, merely risk losing the civil case at hand. What is decisive is that the structure of a civil case differs from a criminal one, since it inevitably involves the need to strike a proper balance between the conflicting rights of two equal parties. When striving to protect the constitutional rights or legitimate expectations of one party in a civil case, the court should take into account equally important constitutional rights and legitimate interests of the other party. Hence, the traditional, absolute application of the nemo tenetur edere contra se principle in civil litigation must be rejected ${ }^{70}$. A proper balance between legitimate expectations and constitutional rights of both parties should be stricken. It

regime contained in the Competition Act itself regulates solely the more fundamental issues, with the Decree on the procedure for granting immunity from fines and reduction of fines in cartel cases contains the rules on procedure'.

${ }^{67}$ In order to be granted relief from sanctions in a leniency programme the offender must, pursuant to the PRCA-1, inter alia, fully and completely disclose its participation in the alleged cartel and cooperate with the NPA throughout the procedure. For other conditions and for general assessment see: supra note 56.

68 Ibidem.

${ }^{69}$ See N. Andrews, supra note 6, at p. 55.

70 Accord: R. Stürner, supra note 14, at p. 169. 
should be borne in mind that especially in litigations which are either complex or characterized by an unequal position of the parties concerning their ability to obtain evidence (like antitrust damages cases), effective access to justice is inherently linked to access to information.

Additional reasons might exist linked to the fate of civil justice in communist Yugoslavia that add to the general underdevelopment of this issue in Slovenia not only in legislation and case law, but also in legal writing. The old procedural system highly valued the so-called principle of material truth. Yet it might seem surprising on first glance that in reality, it contained so few instruments which would enable parties to search for that truth. Nevertheless, the absence of such instruments in the hands of the parties used to be 'compensated' by broad inquisitorial powers of judges. It is not so surprising therefore that the parties' lack of access to documents held by others (their opponent or a $3^{\text {rd }}$ party) was not perceived as important. Judges used to be empowered to take evidence ex officio, alongside broad inquisitorial powers to require the production of any kind of documents, irrespective of who held them. Hence, it was simply expected that if a party fails to gain access to relevant evidence, the judge would take it ex officio and invoke the courts' broad inquisitorial powers. Slovenian law still contains the rule that judges have broad powers to seek documents from any persons (Article $10 \mathrm{CPA}$ ). Nevertheless, this rule has lost much of its significance due to the fact that judges are no longer empowered to take evidence ex officio, except in regard to procedural pre-requisites (such as jurisdiction) or in exceptional circumstances and certain specific types of disputes (such as family cases).

A closer look at some principles and rules of civil procedure of communist Yugoslavia shows how unfavourable the creditor's position used to be. For instance, the standard of proof in civil cases has always been very high, closely resembling, by law, the standard applied in criminal cases ('the judge must be convinced...' $)^{71}$. A strict and absolute (no exceptions) prohibition of so-called 'exploratory' or 'informative evidence' applied at least until very recently ${ }^{72}$.

71 The judge must be (practically) convinced (persuaded) about the existence of a certain fact, if not, the judge should rule against the party carrying the burden of proof for this fact. Hence, even if the court finds it more probable - but still not with a degree beyond a doubt of a reasonable person - that this fact actually exists (Judgment of the Supreme Court, II Ips 492/2002, 8.7.2004: '( ...)convinced of the existence of material fact beyond doubt of any reasonable person'). The harshness of the high standard of proof is sometimes relaxed in doctrine as well as case law where a solution is applied that the standard of proof in a civil case should not, as Art. 216 CPA implies, be practically identical to the one in criminal cases (beyond reasonable doubt); therefore, a clearly overwhelming degree of probability should be sufficient in a civil case (see: ibidem). However, a mere decision on the preponderance of probabilities is definitely not sufficient.

72 Eg judgment of the Supreme Court No. II Ips 106/2001 of 5 July 2002. 
That prohibition was stricter than in Germany, for instance, where the doctrine and the case law have developed a balanced approach to the acceptability of Ausforschungsbeweis ${ }^{73}$. An absolute prohibition of such adducing of evidence is not justified in cases where the litigants must allege facts that lie outside their range of perception and hence do not have sufficient knowledge of the necessary facts ${ }^{74}$. In such cases, it is on the one hand necessary to alleviate the requirements of substantiated allegation of facts, and on the other hand, to allow informative evidence in order to ensure a fair trial ${ }^{75}$.

It should also be noted that in Slovenian civil procedure the claimant needs to - without exceptions - define a specific prayer of relief (a precise amount of money sought) already in the claim. The claimant cannot wait for the results of expert evidence, for instance, which makes it possible to determine damages effectively. Moreover, the strict principle of 'the loser pays' applies and costs of pre-action party-appointed experts are only exceptionally reimbursable. All of the aforementioned features, in addition to the lack of adequate possibilities of access to information, show that the claimant's position in Slovenian civil procedure is rather difficult. This is so compared not only to the common law systems, but also to other civil law systems. Many of these national features were inherited from the procedural regime of the communist era, despite the fact that it was supposed to have been a system which attached great importance to the finding of 'material truth'. The entirely inadequate rules on the protection of business secrets in the Slovenian CPA are also a heritage of the communist era ${ }^{76}$.

The present situation in Slovenia is unsatisfactory because a court disclosure order for evidence can only be issued at the trial stage of the civil proceedings, and even this is true to a rather limited extent only. Experience and recent developments abroad - also in other civil law systems ${ }^{77}$ and on

73 Cf. R. Stürner, supra note 14, at p. 172.

$74 \mathrm{M}$. Dolenc, 'O vlogi informativnega dokaza v pravdnem postopku' ['On the role of informative evidence in civil proceedings'] (2011) 6-7 Podjetje in delo 1467.

75 The Slovenian Supreme Court adopted such view for the first time in its judgment No. II Ips 302/2011 of 26 April 2012.

76 Although, unlike in the countries of the Soviet bloc, a system of a 'centrally planned economy' did not apply in Yugoslavia, the principles of free market and private initiative were not recognized either, hence also the lack of proper procedural protection of business secrets vis-à-vis their adversaries in litigation.

${ }^{77}$ In Germany, since the ZPO reform in 2002, the court is empowered to seek the production of documents - from the other party and from $3^{\text {rd }}$ persons - based solely on their relevance to the pending case. $3^{\text {rd }}$ parties are protected from having to submit evidence to the extent that this would be unreasonable or that the documents are protected by a statutory witness privilege. It is still debated how far reaching this new rule might be but the prevailing view is that it amounts to a paradigm shift and is a major step in the direction of a general duty to disclose and produce evidence (H. Prütting, 'International Sources of German Civil Procedure' [in:] 
a level of academic attempts to harmonize civil procedure ${ }^{78}$ - show that this restrictive approach to disclosure of documents needs to be re-examined. The creation of an EU-wide litigation disclosure mechanism in the Damages Directive will therefore inevitably have a general impact on civil procedure law in Slovenia. It is true that the EU-wide litigation disclosure mechanism, as established by the Directive, does not fit into existing Slovenian law (where disclosure merely follows rather precise fact pleading and is not a tool for gathering information ${ }^{79}$ ). It is equally true that the Directive's disclosure mechanism, if introduced, would amount to a radical change in procedural philosophy. It is however very doubtful that Slovenia's existing procedural system enables 'effective private enforcement of antitrust' 80 . The fact that there are practically no cases of successful and, in fact, even attempted private

M. Deguchi, M. Storme, The Reception and Transmission of Civil Procedural Law in the Global Society, Maklu, Antwerpen 2008, p. 257). In France, pursuant to Art. 11 NCPC, when a party possesses relevant documents, the judge can, at the request of the other party, order the party to produce it. Unless legitimate grounds for withholding the document exist, the judge can fine the party for delay (and draw adverse inferences in cases of non-compliance). The judge can, upon the request of a party, also request a $3^{\text {rd }}$ party to submit documents unless legitimate grounds for withholding them prevail (eg protection of professional secrecy; see F. Ferrand, 'The Respective Role of the Judge and the Parties in the Preparation of the Case in France' [in:] N. Trocker, V. Varano, The reforms of civil procedure in comparative perspective, Giappichelli Editore, Torino 2005, p. 27). Also the new Dutch Civil Procedure Act of 2002 extended the possibilities through which a litigation party can effectively seek the production of documents in possession of the opposing party (Art. 22). A document can be requested if it is relevant to the pending dispute and it may be withheld only for 'compelling reasons'. This is in line with the (also newly introduced) and 'decidedly revolutionary'; G.R. Rutgers, J.W. Rutgers, 'Reform of the Code of Civil Procedure in the Netherlands' [in:] N. Trocker, V. Varano, The reforms of civil procedure in comparative perspective, Giappichelli Editore, Torino 2005, p. 140) principle that parties must 'fully and truthfully supply facts that are relevant for the judge's decision under the threat of drawing adverse inherences in case of non-compliance' (Art. 21). The new Swiss Federal Civil Procedure Act (in force since 2011) provides for far reaching obligations of the parties and $3^{\text {rd }}$ parties to disclose and produce documents (Art. 160 FCPA).

78 An important indication of convergence between civil and common law approaches when it comes to evidence disclosure can be found in the ALI/UNIDROIT Principles of Transnational Civil Procedure of 2004. Article 16.2 provides for limited disclosure under the supervision of the court. It states that 'upon timely request of a party, the court should order disclosure of relevant, non-privileged, and reasonably identified evidence in the possession or control of another party or, if necessary and on just terms, of a non-party.' By stating that 'It is not a basis of objection to such disclosure that the evidence may be adverse to the party or person making the disclosure' the Principles explicitly eliminates the old-fashioned continental understanding of the privilege against self-incrimination in civil cases. Still, the explanatory memorandum also makes clear that 'fishing expeditions' should not be allowed.

79 N. Bucan Gutta, supra note 37, at p. 224.

${ }^{80}$ For such view see: ibidem. For a more critical view see: M. Brkan, T. Bratina, supra note 36 , at p. $105-106$. 
enforcement, speaks for itself. Moreover, the state of great uncertainty as to whether any confidential information and business secrets is exempt from disclosure obligations additionally jeopardizes the legitimate interests of potential defendants in such litigation.

The transposition of the Directive's litigation disclosure mechanism will require a fundamental change in Slovenia's key procedural principles ${ }^{81}$. It would be naïve to expect that such move could indeed be achieved if it was limited (isolated) to the very particular area of private antitrust enforcement - possibly by a mere minimalistic transposition of the Directive's requirements in a copy-paste manner (frequently the case in Slovenia). It is not realistic to expect that the new harmonized disclosure system can be properly and effectively applied by judges, who in all other cases perceive the scope and the purpose of disclosure in an entirely different manner and still adhere to the perception that a party cannot be required to disclose evidence which harms them ${ }^{82}$.

It should also be taken into account that the system promoted by the Directive relies heavily on the application of the principle of proportionality (for instance concerning the degree of protection of business secrets) and extends the use of open-ended terms in procedural legislation, all based on a presumption that judges can be trusted to apply them appropriately. Yet the majority of Slovenia's legal community - judges and attorneys alike - still prefers a rigid procedural regime with detailed rules. They frown upon any attempts to provide more room for judges to adapt the unfolding of proceedings to the characteristics of each particular case. This can also constitute a major impediment to the effectiveness of the litigation disclosure mechanism since the latter promotes, by contrast, the application of open-ended rules and general principles. Finally, the role of practicing attorneys should not be underestimated either. Preparing requests for evidence disclosure requires a great amount of diligent and time-consuming work. This, however, can hardly be expected from those lawyers who have difficulties to engage in a diligent and timely search for information and documents in possession of their own clients (see supra, section III subsection 1). Currently, there are merely a handful of law firms in Slovenia which are realistically capable of properly applying the disclosure mechanism foreseen in the Directive.

In conclusion, it is true that the transposition of the litigation disclosure mechanism of the Damages Directive will undermine the existing principles of Slovenian civil procedure. This, however, is due to the fact that Slovenian

81 Ibidem.

82 Cf. (for Germany): W.-H. Roth, 'Private Enforcement of European Competition Law - Recommendations Flowing from the German Experience' [in:] J. Basedow (ed.), Private Enforcement of EC Competition Law, Kluwer Law International, 2007, p. 77. 
law is outdated with regard to the issue of evidence disclosure and is partially based on erroneous premises. The required transposition of the Directive's requirements should therefore be perceived as a step in the right direction for Slovenia. This step will, however, be successful only if followed by a general reassessment of disclosure of evidence rules in Slovenian civil procedure law.

\section{Literature}

Andrews N., English Civil Procedure, University Press, Oxford 2003.

Ashworth A., 'Self-Incrimination in European Human Rights Law - a Pregnant Pragmatism' (2008) 30(3) Cardozo Law Review 751-774.

Bergant Rakočević V., 'Varstvo uradne, vojaške in poslovne tajnosti v civilnem sodnem postopku' (2011) 6-7 Podjetje in delo 1476-1486.

Brkan M., Bratina T., 'Private Enforcement of Competition Law in Slovenia: A New Field to Be Developed by Slovenian Courts' (2013) 6(8) YARS 75-106.

Bucan Gutta N., The Enforcement of EU Competition Rules by Civil Law, Maklu Uitgevers, 2014.

Burrows E., Sander R., 'Impact of the EU Directive on Antitrust Damages Actions England \& Wales - Competition Litigation 2015' [in:] Competition Litigation 2015. International Comparative Legal Guides, 7th edition, 2014.

Caufmann C., Philipsen N.J., 'Who Does What in Competition Law: Harmonizing the Rules on Damages for Infringements of the EU Competition Rules?' (2014) 19 Maastricht European Private Law Institute Working Papers, http://ssrn.com/abstract=2520381, http:// dx.doi.org/10.2139/ssrn.2520381.

Cary J., Kilaniotis L., McGregor A., Smith S., 'United Kingdom: Private Antitrust Litigation' [in:] The European Antitrust Review, 2015, Chapter 71, http://globalcompetitionreview. com/reviews/62/sections/210/chapters/2530/united-kingdom-private-antitrust-litigation/.

Choo A., The Privilege Against Self-Incrimination and Criminal Justice, Hart Publishing, 2014.

Dolenc M., 'O vlogi informativnega dokaza v pravdnem postopku' (2011) 6-7 Podjetje in delo $1467-1475$.

Fatur A., Podobnik K., 'SI/C Slovenia/Commentary' [in:] Competition Law in Western Europe and the USA, Wolters Kluwer, 2014, Chapter SI.C-1.

Fatur A., Podobnik K., Vlahek A., 'Competition Law - Slovenia' [in:] F. Denozza; A. Toffoletto (eds.), International Encyclopaedia for Competition Law, Kluwer Law International/Wolters Kluwer, forthcoming (expected date of publication 2015), Chapter 5, § 1, IV B.

Ferrand F., 'The Respective Role of the Judge and the Parties in the Preparation of the Case in France' [in:] N. Trocker, V. Varano, The reforms of civil procedure in comparative perspective, Giappichelli Editore, Torino 2005, p. 7-32.

Leipold D. [in:] Stein \& Jonas, ZPO-Kommentar, 22. Aufl., Mohr Siebeck, Tübingen 2005. Prütting H., 'International Sources of German Civil Procedure' [in:] M. Deguchi, M. Storme, The Reception and Transmission of Civil Procedural Law in the Global Society, Maklu, Antwerpen 2008, p. 249-260. 
Rutgers G.R., Rutgers J.W., 'Reform of the Code of Civil Procedure in the Netherlands' [in:] N. Trocker, V. Varano, The reforms of civil procedure in comparative perspective, Giappichelli Editore, Torino 2005, p. 131-142.

Roth W.-H., 'Private Enforcement of European Competition Law - Recommendations Flowing from the German Experience' [in:] J. Basedow, Private Enforcement of EC Competition Law, Kluwer Law International, 2007, p. 61-81.

Stürner R., 'Duties of Disclosure and Burden of Proof in the Private Enforcement of European Competition Law' [in:] J. Basedow, Private Enforcement of EC Competition Law, Kluwer Law International, 2007, p. 164-191.

Triva S., Belajec S., Dika M., Građansko parnično procesno pravo, Narodne Novine, Zagreb 1986.

Trocker N., Varano V., 'Concluding remarks' [in:] N. Trocker, V. Varano (eds.), The reforms of civil procedure in comparative perspective, Giappichelli Editore, Torino 2005.

Testen M., 'Vloga odvetnika pri pridobivanju in (ne)razkritju dokazov za namen pravdnega postopka' (2011) 6-7 Podjetje in delo 1499-1509.

Ude L., Pravdni postopek - zakon s komentarjem, vol. 2, GV Založba in ČZ UL, Ljubljana 2006.

Ude L., Civilno procesno pravo, ČZ UL, Ljubljana 2002.

Uzelac A., 'Survival of the third legal tradition?' (2010) Supreme Court Law Review 377-396.

Vlahek A., 'Nova Direktiva 2014/104 o nekaterih pravilih glede odškodninskih zahtevkov in postopka zaradi kršitev evropskega in nacionalnega prava' [in:] P. Grilc (ed.), Liber Amicorum Bojan Zabel, Pravna fakulteta v Ljubljani, 2015, p. 171-202.

Vlahek A., 'Challenges of Private Enforcement of Antitrust in Slovenia' [in:] A. Gerbrandy, M. Kovač (eds.), Economic Evidences in EU Competition Law. European Studies in Law and Economics, Intersentia, Mortsel-Cambridge 2015 (forthcoming).

van Rhee C.H., 'Dutch Civil Procedural Law in an International Context' [in:] M. Deguchi, M. Storme, The Reception and Transmission of Civil Procedural Law in the Global Society, Maklu, Antwerpen 2008, p. 191-212.

Wagner G., 'Harmonisation of Civil Procedure: Policy Perspectives' [in:] X.E. Kramer, C.H. van Rhee, Civil Litigation in a Globalising World, Springer, Cham-HeidelbergDordrecht-New York-London 2012, p. 93-119.

Wardhaugh B., Cartel Leniency and Effective Compensation in Europe: The Aftermath of Pfleiderer, Queen's University Belfast Law Research Paper No. 23, http://ssrn.com/ abstract $=2330243$, http://dx.doi.org/10.2139/ssrn.2330243. 